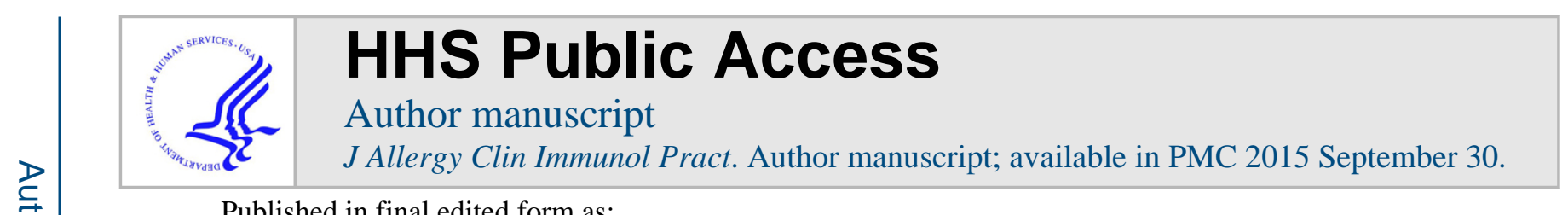

Published in final edited form as:

J Allergy Clin Immunol Pract. 2014 ; 2(5): 489-500. doi:10.1016/j.jaip.2014.06.022.

\title{
Severe asthma in children
}

TW Guilbert, MD ${ }^{\mathrm{a}}$, LB Bacharier ${ }^{\mathrm{b}}$, and AM Fitzpatrick ${ }^{\mathrm{c}}$

${ }^{a}$ Cincinnati Children's Hospital, Cincinnati, $\mathrm{OH}$

bWashington University School of Medicine and St. Louis Children's Hospital, St. Louis, MO

'Emory University, Atlanta, Ga

\section{Abstract}

Severe asthma in children is characterized by sustained symptoms despite treatment with high doses of ICS or oral corticosteroids. Children with severe asthma may fall into two categories, difficult-to-treat asthma or severe therapy-resistant asthma. Difficult-to-treat asthma is defined as poor control due to an incorrect diagnosis or comorbidities, poor adherence due to adverse psychological or environmental factors. In contrast, treatment-resistant is defined as difficult asthma despite management of these factors. It is increasingly recognized that severe asthma is a highly heterogeneous disorder associated with a number of clinical and inflammatory phenotypes that have been described in children with severe asthma. Guideline based drug therapy of severe childhood asthma is based primarily on extrapolated data from adult studies. The recommendation is that children with severe asthma be treated with higher-dose inhaled or oral corticosteroids combined with long-acting beta-agonists and other add on therapies such as antileukotrienes and methylxanthines. It is important to identify and address the influences that make asthma difficult to control including reviewing the diagnosis and the removal of causal or aggravating factors. Better definition of the phenotypes and better targeting of therapy based upon individual patient phenotypes is likely to improve asthma treatment in the future.

\section{Keywords}

Childhood severe Asthma; Childhood difficult-To-Treat Asthma; Severe asthma phenotypes; Childhood severe asthma treatment; Review

\begin{abstract}
Asthma is the most common chronic lung disease of childhood that affects $>6.6$ million children in the United States(1). Most children with asthma achieve good symptom control when treated with low-to-medium doses ( $<500 \mathrm{mcg} /$ day fluticasone equivalents) of inhaled corticosteroids (ICS). However, severe asthma in children is characterized by sustained symptoms despite treatment with high doses of ICS or oral corticosteroids $(2,3)$ and represents approximately $5 \%$ of childhood asthma cases(4). Although this form of asthma is the least common, it accounts for nearly $50 \%$ of all asthma-related expenditures $(5,6)$. It has been suggested that children with severe asthma may fall into two categories, difficult-to-
\end{abstract}

${ }^{a}$ Corresponding author: Theresa Guilbert, M.D., The Department of Pediatrics, Division of Pulmonology Medicine, Cincinnati Children's Hospital \& Medical Center, 3333 Burnet Avenue, MLC 2021, Cincinnati, OH 45229, Office: (513) 803-0493, Theresa.Guilbert@cchmc.org. 
treat asthma or severe therapy-resistant asthma. Difficult-to-treat asthma is defined as poor control due to an incorrect diagnosis or comorbidities, poor adherence due to adverse psychological or environmental factors. In contrast, treatment-resistant is defined as difficult asthma despite management of these factors(7). Data suggest that children with severe asthma begin demonstrating symptoms early in life, and the majority have atopy and reversible airway obstruction $(8,9)$. Although these data have helped define the scope of this disease in children, there are numerous questions left unanswered. This review will focus on severe asthma in school-aged children (5-17 years) from definition to management.

\section{Severe Asthma in Children Is Different than Adult Disease}

Extrapolating adult severity classifications to children is difficult for a number of reasons. Adults with asthma are more likely to exhibit a persistent pattern; while, children may have a pattern of rapidly evolving, frequent and often severe exacerbations. Children have severe exacerbations triggered by viral infections and/or allergen exposure that can result in healthcare utilization but then often remain asymptomatic between these episodes $(10,11)$. Phenotypes of severe asthma in children differ from those of adults and change more rapidly. It is therefore necessary to reassess phenotypes at regular intervals. Responses to medications(12) and the more pronounced growth and bone maturation adverse effects of ICS(13) also differ between childhood and adult asthma. Lung function measurements also show different patterns, are age-dependent, and may be within normal limits despite significant symptom burden and medication use(14-16). The distal airways are more affected, and increased distal lung resistance, in the absence of significant large airway involvement, likely explains the often unimpaired FEV1 values(17). Furthermore, other measures of lung function such as FEV1/forced vital capacity (FVC), FEF25-75\% predicted, or the degree of airway responsiveness to bronchodilators may relate better to asthma severity(15). Children, particularly boys, demonstrate more hyperinflation with increased residual volume and total lung capacity. (18). Girls with severe asthma also exhibit some air-trapping and airflow limitation during bronchodilator abstinence, but to a lesser magnitude than seen in boys, and this finding is generally reversible with bronchodilation(19).

Epidemiology studies suggest that children with atopic asthma have a slow decline in lung function over time $(14,20,21)$. This decline in lung function may be accelerated in children with severe asthma. Children with severe asthma typically are more atopic with higher serum IgE levels and demonstrate reversible airway obstruction compared to their adult counterparts. Children with severe asthma are differentiated by higher exhaled nitric oxide (FENO), higher IgE and eosinophils, and differential patterns of sensitization to aeroallergens, especially molds(3). Severe asthma may be due to underlying severity of the disease from persistent airway inflammation and relative corticosteroid insensitivity(22-24) or poor asthma control due to a number of biological, environmental, and/or social factors(7, $25,26)$. Adolescents are at an increased risk of a higher prevalence of severe asthma and death from asthma due to reduced adherence to treatment and increased risk-taking behaviors (smoking, illicit drug use). Poor adherence is also associated with complex treatment regimens, familial strain, inadequate supervision of the child, and possible secondary gains linked to poorly controlled asthma(27). Poor asthma control may be due to 
the child's clinician failing to use evidence based asthma treatment guidelines or failure to assess a child's symptom burden adequately(28). Finally, children can have co-morbid conditions such as sinusitis and vocal cord dysfunction that may exacerbate or mimic asthma but will not respond to asthma treatment.(9)

\section{Epidemiology of Severe Asthma}

Epidemiologic studies have described risk factors for severe asthma and airway hyperresponsiveness. Many children with severe asthma present in school age (6-11 years); however, they report the onset of asthma symptoms earlier in childhood (first 3 years of life) than children with mild-to-moderate asthma $(5$ years $)(3,29)$. Another risk factor for asthma and severe airway hyperresponsiveness may be lower lung function present shortly after birth. Infants with the lowest pulmonary function (fraction of expiratory time to peak tidal expiratory flow) had a higher risk of current asthma and severe airway hyperresponsiveness at 10 years of age(30) and increased airway obstruction on lung function testing at 22 years(31) compared to infants with higher lung function. Children with severe asthma also had increased airway obstruction and air trapping $(2,14,32-34)$. Moreover, children with airway hyperresponsiveness at 9 years of age were three times more likely to develop functional abnormalities (low postbronchodilator FEV1/vital capacity ratio) in adolescence and early adulthood that may reflect underlying structural airway remodeling(35). In longitudinal cohort studies, subsets of children with asthma demonstrate decline in lung function over time(36)

In school-aged and adolescent children, those with severe asthma were more likely to have increased allergic sensitization (serum IgE), more aeroallergen skin prick responses early in life, a higher prevalence of atopic dermatitis, greater bronchial hyperresponsiveness, airway obstruction, higher FENO and to report being of African American or more than one race than children with milder disease $(3,6,20,29,35,37,38)$

\section{Severe Asthma Definitions}

Although several definitions of "severe asthma" have been proposed, no single definition has gained universal acceptance due to the complex nature of the disease and the lack of validated gold standards for diagnosis. To further complicate matters, "asthma" itself is a highly heterogeneous condition that remains poorly understood in children. In a recent review of large cohorts of school-age asthma children, 122 publications yielded 60 different operational definitions of asthma that greatly impacted prevalence and clinical outcome assessments(39). Nonetheless, the traditional views of asthma as proposed by both the National Asthma Education and Prevention Program (NAEPP)(40) and the Global Initiative on Asthma (GINA)(41) assume that: 1) asthma is a single disease entity with a spectrum of inflammation, 2) there is concordance between inflammation and symptoms, and 3) that the nature of inflammation is responsive to corticosteroid treatment. According to these guidelines, severe asthma corresponds to the "top" of the disease spectrum and is therefore thought to be associated with a high degree of airway inflammation and resulting symptoms. Thus the proposed definitions of severe asthma are based on symptom burden, short-acting beta-agonist use, limitation of activities, frequency and severity of exacerbations, and lung 
function (Table 1). However, it's important to note that asthma severity is assessed before treatment is initiated and the criteria often overlap with those used for asthma control once treatment is initiated.

In 1999, an American Thoracic Society Workshop on Refractory Asthma (42) was convened to further refine the definition of severe asthma. This definition required that a patient with persistent asthma be treated with continuous high-dose ICS or continuous oral corticosteroids to maintain asthma control and also have at least two minor criteria consistent with historical or current poor asthma control. This definition was recently revised in a joint workshop convened by the American Thoracic Society and the European Respiratory Society and currently distinguishes between patients with treatment-resistant severe asthma and patients in whom the asthma is difficult to treat due to co-morbid and other complicating factors(27). It is important to note that this definition of severe asthma was developed for countries in which there is access to asthma medications. An alternative definition of severe asthma for global health application was proposed by the World Health Organization(43) and recognizes the existence of a group of patients with untreated severe asthma who may either be undiagnosed due to limited training and availability of medical staff or under-treatment due to limited access to medical care and pharmacologic therapies.

\section{Heterogeneity of Severe Asthma in Children}

It is increasingly recognized that severe asthma is a highly heterogeneous disorder associated with a number of clinical and inflammatory phenotypes that can be assessed through detailed analysis of induced sputum, bronchoalveolar lavage, or endobronchial biopsy (44-47). Although this research is incomplete, particularly in children with severe asthma, three phenotypes of airway inflammation have been described: (1) eosinophilic inflammation $(48,49)$; (2) paucigranulocytic inflammation $(48,49)$ and (3) neutrophilic inflammation $(44,48,49)$. Children with an eosinophilic phenotype are typically identified in the pre-school or early school-age years(50) and are characterized by increased symptoms, less controlled disease, more atopy, impaired lung function, increased airway hyperresponsiveness, and an increased frequency of exacerbations compared to the other phenotypes $(49,51)$. While the eosinophilic phenotype is thought to be more corticosteroidresponsive (52), the contribution of the eosinophilia in children is unclear. Although studies in adults have demonstrated fewer exacerbations in patients treated with sputum eosinophilia-guided therapy (53), Fleming et al.(54) found that incorporation of sputum eosinophils into the management of school-age children with severe asthma did not significantly reduce exacerbations or improve asthma control. Moreover, the levels of inflammatory cells in induced sputum varied significantly over time and were unrelated to changes in asthma pharmacotherapy or asthma control(54). However, a subset of children with severe asthma and persistent eosinophilia after high-dose systemic corticosteroid administration has been described(55). While increased reticular basement membrane thickening and increased airway smooth muscle mass also characterize these children, they have a relative absence of classical Th2 cytokines such as IL-4, IL-5 and IL-13 that are commonly seen in adults(56). 
The neutrophil inflammatory phenotype may be present in children with asthma of asthma at all ages(57) and may be associated with poor response to corticosteroids(55). Causes for neutrophilic inflammation are currently being explored but have been postulated to include environmental exposures such as air pollution or infections. In adults, a higher proportion of sputum neutrophils is associated with smoking(58) and in children with viral infection(59, 60). This may explain both the ineffectiveness of doubling the dose of ICS and the potential efficacy of quadrupling the dose at the onset of exacerbations $(57,61)$. While airway neutrophils have been reported in a subset of children with severe asthma(62), this finding has not been consistently replicated across populations. Bossley et al. recently found no evidence of neutrophilic airway inflammation in a large bronchoscopic study of children with severe, therapy-resistant asthma. Other studies suggest that neutrophils may (56)coexist with eosinophils in the airway tissue and epithelial lining fluid $(2,63)$, so the causative role of the neutrophil, if any, is unclear since issues of confounding by high-dose corticosteroid treatment remain. While additional studies are needed, these differential airway inflammatory patterns may ultimately permit identification of specific phenotypes of severe asthma to aid in directed, pharmacologic treatment..

\section{Severe asthma phenotypes based on cluster analyses}

Severe asthma in children is a highly complex disorder and the relationships between pathogenesis, airway inflammation and clinical treatment remain poorly understood. Given the limitations of existing definitions of severe asthma (which are inherently biased), there is a growing interest in non-biased statistical approaches to identify potential biomarkers and ultimately permit more personalized, pharmacologic therapy. Cluster analysis is a technique that groups patients into "clusters" who share clinical, physiologic, and/or biological characteristics. The NHLBI Severe Asthma Research Program recently performed a cluster analysis of 12 continuous and composite variables from 161 children. Four clusters of asthma were identified which varied according to the age of asthma onset, the degree of lung function impairment and the number of asthma controller medications. Children with severe asthma were present in all four clusters, and no one cluster perfectly fit the definitions of asthma severity provided in asthma treatment guidelines (64). Separate cluster analyses in European children have also identified clusters of children with severe asthma who were differentiated by the degree and nature of allergic sensitization, body mass index, and airflow obstruction $(65,66)$. Recently, a cluster analysis in a combined sample of children and adults with severe or difficult-to-treat asthma also noted separate clusters within each age stratum. Interestingly, passive smoke exposure was a distinguishing variable in children, while aspirin sensitivity was a distinguishing variable in adolescents and adults(67). Altogether, these studies highlight the heterogeneity in the clinical presentation of severe asthma in children. Replication and longitudinal validation of clustering approaches for asthma is ultimately needed to determine the association between cluster assignment and asthma outcomes. However, these methods may be useful in the refinement of the definition of severe asthma to be used in upcoming studies 


\section{Severe asthma phenotypes based on molecular analysis}

Given the relative infrequency of severe asthma in the pediatric population, large-scale molecular investigations of children with severe asthma have not yet been undertaken. Therefore most studies in this area have compared children with severe and non-severe asthma but have been limited in their ability to identify sub-populations. Regardless, distinct inflammatory patterns have been observed in invasive bronchoscopy studies (56, 63). Other studies have shown that children with severe asthma have altered regulation of antioxidant defenses(68-73) and growth factor expression that is associated with the magnitude of airflow obstruction. Other molecular investigations are warranted in children, particularly in tandem with non-biased phenotyping approaches.

\section{Severe asthma phenotypes based on genetics}

Genetic variations may play an important role in severe asthma and ultimately may account for altered corticosteroid responsiveness in this population. While several genome-wide association studies (GWAS) have been undertaken in healthy versus asthmatic populations to determine the genes associated with the development and onset of asthma, genetic analyses of asthma severity particularly in children are extremely limited. A large GWAS of severe asthma and healthy adult controls of European ancestry observed two previouslyidentified asthma susceptibility loci (ORMDL3/GSDMB locus on chromosome 17q12-21 and IL1RL1/IL18R1 locus on chromosome 2q12), but no novel loci for severe asthma susceptibility were identified(74). In a recent meta-analysis of GWAS conducted in predominantly healthy adult populations of European whites, genes in the INTS12-GSTCD$N P N T$ region were associated with the forced expiratory volume in one second $\left(\mathbf{F E V}_{\mathbf{1}}\right)$ while eight genes (HHIP, GPR126, ADAM19, AGER-PPT2, FAM13A, PTCH1, PID1, and $H T R 4)$ were associated with the ratio of $\mathrm{FEV}_{1}$ to forced vital capacity (FVC)(75). A similar meta-analysis also identified four genes (HHIP, GSTCD, TNS1, and HTR4) associated with $\mathrm{FEV}_{1}$ and three loci (HHIP, NOTCH4-AGER-PPT2, THSD4) associated with FEV I $^{\prime}$ FVC(76). The NHLBI Severe Asthma Research Program also performed a meta-analysis of lung function and GWAS results in five racially diverse asthmatic pediatric and adult populations across a wide range of severities and discovered a panel of genes (HHIP, FAM13A, PTCH1, PID1, NOTCH4) associated with lung function that differed from these previous reports(77). Moreover, Th1 pathway genes associated with innate defense and inflammation have been shown to modify the association with lung function in asthmatic patients(78). The finding that combinations of risk SNPs (versus single risk SNPs) identified asthmatics with greater deficits of lung function is novel and argues strongly for additional additive genetic approaches in the identification of asthma severity. Other genes ( $\mathrm{CHRHI}$, TBX21 and FCER2) have also been implicated in the response to corticosteroids and these associations were replicated in several adult and pediatric cohorts(79-81).

\section{Differential Diagnosis}

Several diseases that mimic asthma should be considered during the evaluation of a child with severe or difficult asthma (Table 2). These include: structural airway abnormality, Intrabronchial obstruction, aspiration, gastroesophageal reflux with/without recurrent 
microaspiration, cystic fibrosis, ciliary cyskinesia, immune dysfunction, bronchiectasis, pulmonary edema, lung disease of prematurity, bronchiolitis obliterans syndrome, hypersensitivity pneumonitis.

\section{Laboratory, Pulmonary Function, Bronchoscopic Evaluation}

Evaluation of a child with severe or difficult asthma may include physiological measurements such as pre- and post-bronchodilator spirometry and body plethysmography. It can include assessment of airway inflammation such as FENO,, sputum eosinophils (research tool), bronchoscopy with bronchoalevolar lavage and bronchial biopsy, and tests for allergic sensitization such as specific allergen IgE or aeroallergen skin prick tests or additional evaluation for comorbidities or diseases that mimic asthma(Table 2). Finally, the coexistence of corticosteroid receptor and pharmacokinetic abnormalities has been associated with a poor response to corticosteroids in children. As such, testing performed at specialized centers for corticosteroid sensitivity could be considered such as a corticosteroid pharmacokinetic studies and corticosteroid lymphocyte stimulation assays $(82,83)$.

ATS/ERS 2014 guidelines on severe asthma recommend that chest CT scans be obtained only when atypical symptoms are present, and do not recommend collection of sputum eosinophils or FENO routinely in children based on available data(27).

\section{Comorbidities}

Severe asthma in children is associated with several comorbidities such as obesity, gastroesophageal reflux, dysfunctional breathing and mental disorders that may exacerbate the severity of asthma symptoms. Evaluation for these disorders should be considered(Table 2).

\section{Obesity}

Interactions between obesity and asthma are complex. Obesity might lead to dyspnea due to deconditioning, a pauci-inflammatory form of asthma(84) and corticosteroid resistance(85). Conversely, the impact of asthma on exercise tolerance and its treatment side effects might contribute to obesity.

\section{Gastroesophageal reflux (GERD)}

The evidence that symptomatic GERD causes asthma or its treatment improves asthma symptoms is unclear $(86,87)$. Furthermore, a recent trial of 306 children with asthma found that treatment of asymptomatic GERD with lansoprazole was not associated with decreased asthma symptoms or improvement in lung function(88). Albeit, it has been suggested that when symptomatic GERD is present, it should be treated as appropriate $(9,27,89,90)$.

\section{Rhinitis/Sinusitis}

Allergic rhinitis and sinusitis are very common comorbidities in patients with asthma, both in children and in adults(91-93). It is not completely understood if the treatment of sinusitis improves outcomes in severe asthma, however, it has been suggested that when sinusitis is present, it should be treated as appropriate(27). 


\section{Vocal cord dysfunction}

Dysfunctional breathing are common in patients with asthma and its symptoms often mimic that of asthma $(94,95)$. Furthermore, up to $15-50 \%$ of children with asthma have been found to have vocal cord dysfunction(96).

\section{Psychological Factors}

Depression and anxiety are well know to be important risk factors for frequent asthmarelated emergency room visits and mortality(97). These psychological factors may act directly through neurally mediated pathways and have effects on adherence(98).

\section{Aspirin Sensitivity and Endocrine Factors}

A number of conditions that can contribute to asthma severity are well recognized in adults with asthma and may sometimes be relevant in children. These include aspirin sensitivity and endocrine factors including exacerbations in relation to the menstrual cycle(99).

\section{Evaluation}

Recent research on severe asthma suggests that a structured approach to evaluation and therapy is important $(46,100)$. First, the child should be assessed for disorders that may mimic asthma (see differential diagnosis section). In 37 young children with severe wheezing unresponsive to therapy, Saglani et al. found structural abnormalities on bronchoscopy in 36\% and evidence of gastro-esophageal reflux (an abnormal pH study or lipid-laden macrophages on bronchoalveolar lavage) in 57\%(101). Furthermore, the child and family should be evaluated for poor adherence to the treatment regimen. Thorough education regarding how and when to use asthma devices and medications and a written asthma plan should be provided(97). Commonly, it is necessary to review pharmacy or medical records for evidence of poor adherence. Electronic monitoring of medication use is available but is used mainly as a research tool. A careful search for comorbidities or triggers contributing to the severity of asthma such as identifying exposure to environmental allergens or irritants should be completed. Passive or personal tobacco smoke exposure may be associated with poor response to treatment. Smoking cessation programs may be helpful. Screening for psychosocial issues with psychological questionnaires or evaluation may be worthwhile. Regular clinical visits are necessary to complete a diagnostic evaluation, provide extensive trigger, device, and asthma education, and to eliminate factors that are aggravating asthma(97). Validated symptom-based questionnaires for assessing asthma control can be employed and followed longitudinally(102). Home visits may also be useful to evaluate adherence to treatment, exposure to tobacco smoke and allergens, and psychosocial factors(103). Corticosteroid-responsiveness could be evaluated through the use of oral high-dose corticosteroids for 2 weeks or an injectable dose of depot triamcinolone given in the clinic. Symptom and lung function response to corticosteroids are typically assessed 2-3 weeks after these therapies. An observed positive response to triamcinolone would likely be due to enforced adherence and suggest poor adherence to therapy as a cause of poorly controlled asthma(27). 


\section{Management}

\section{Treatment}

\section{Conventional Therapy}

Controllers: At present, guideline based drug therapy of severe childhood asthma is based primarily on extrapolated data from adult studies. The recommendation is that children with severe asthma be treated with higher-dose inhaled or oral corticosteroids combined with long-acting beta-agonists and other add on therapies $(27,41,97)$. Some studies have shown no evidence of secondary prevention of symptoms and prevention of decline of lung function(104-106); wherease, others suggests that early treatment with daily ICS may modify the severity of disease when initiated in childhood leading to less severe asthma exacerbations and a smaller decline in lung function compared to children treated with placebo(107).. However, high doses of ICS are associated with increased risk of adrenal suppression and growth suppression in children(27). Nevertheless, there is evidence in adults with asthma that high dose ICS are less well absorbed from the airway compared to healthy controls $(108,109)$. Thus, in patients with severe asthma with presumably greater airway inflammation, higher doses of ICS may be appropriate. There are few studies of high-dose ICS in children with severe asthma; yet, there is some evidence that oral corticosteroid doses can be lowered if children are treated with higher doses of ICS(110). Thus, close monitoring of growth and/or annual test of adrenal function with consultation with a pediatric endocrinologist if abnormalities are found may be a useful strategy(27).

Small particle ICS: It is debated whether distal/peripheral airway inflammation plays a greater role in severe, therapy-resistant asthma or instead reflects poor distal airway deposition of conventional ICS. Accordingly, the systemic distribution of oral corticosteroids or the use of small particle ICS such as extra-fine beclomethasone or ciclesonide could be a more effective means of targeting the distal airway through improved deposition $(111,112)$. It remains unclear if small particle ICS is more effective than large particle ICS in the treatment of severe asthma. A randomized, prospective study of adults with mild-to-moderate asthma demonstrated improvements in small airway parameters, decreased alveolar exhaled nitric oxide and CT-scan measurements of expiratory lung volume after methacholine challenge, following 5 weeks of ciclesonide treatment compared to placebo(111). Another study using a retrospective matched cohort study from large longitudinal health care claims database trial designs demonstrated better asthma outcomes in adult patients treated with a combination of small particle ICS and a long-acting betaagonist compared to combinations with larger particle ICS $(113,114)$. Similar findings of improved asthma outcomes have been found in other retrospective database studies in adults with poorly controlled asthma treated with large particle ICS compared to small particle ICS monotherapy $(115,116)$. Conversely, meta-analyses of randomized controlled trials have not found differences in asthma outcomes between small and larger particle ICS(117-119). Finally, a crossover comparison of small-particle and larger particle ICS in children 6-12 years showing no additional benefit for treatment with small particle ICS in measures of small airways inflammation(120). 
Oral corticosteroids: A small proportion of children may require continuous oral corticosteroids to keep their asthma under control. Long-term use of high-dose systemic corticosteroids increases risk of systemic side effects such as growth retardation, adrenal suppression, and altered skin and bone metabolism(121-123). If used, the dose should be gradually tapered to the lowest dose that maintains symptom control(27).

Long-acting beta-agonists: These medications, used in conjunction with ICS, are guideline recommended therapy (NAEPP, GINA, ATS/ERS); however, questions regarding increased risk of severe exacerbations particularly in those of African-American descent(124) and lower efficacy in children $(125,126)$ have been raised. A recent study in school-aged children with persistent asthma not controlled on low dose ICS therapy demonstrated that step-up therapy with long-acting beta-agonists was significantly more likely to provide improved asthma symptoms and lung function than either ICS or antileukotriene step-up therapy(127). However, there was marked variability in the treatment response suggesting the need for regular monitoring and adjustment of each child's asthma therapy.

Antileukotrienes: These medications are currently included in multiple guidelines as step-up therapy for the treatment of severe asthma $(41,97)$ and there is recent evidence that it can also be an effective strategy in children, although not as great as long-acting beta-agonist step-up therapy(127). However, in children, it is not clear what the phenotypic characteristics of an antileukotriene responder with severe asthma would be(27). In adults, there is evidence to support its use as step-up therapy in aspirin-sensitive asthma(128). Adult patients requiring high doses of ICSs demonstrate significant improvement in symptoms, lung function, and beta-2-agonist use with high-dose zafirlukast(129).

Methylxanthines: These medications can also be used as step-up treatment to ICS, although the addition of theophylline to ICS produces a small improvement in lung function similar to doubling the dose of ICS(130). Studies on the use of xanthines in combination with ICS (with or without long-acting beta-agonists) in severe asthma are lacking. Given the safety profile of low dose theophylline, it has been proposed for use in adolescents with severe asthma before other treatments $(27,131)$.

Specific Allergen Immunotherapy: Specific allergen immunotherapy has been demonstrated to have beneficial effects in the management of childhood asthma, including effects on symptom control, medication use, and airway hyperresponsiveness(132). A recent meta-analysis examining the efficacy of allergen-specific immunotherapy concluded that there is moderate strength evidence that subcutaneous immunotherapy improves asthma symptoms and high strength evidence that sublingual immunotherapy improves asthma symptoms(133). However, these conclusions are drawn from studies involving children with mild-moderate asthma, as no studies have specifically examined the efficacy of allergen immunotherapy in children with severe asthma. Thus, the generalizability of these findings in pediatric severe asthma is uncertain. Furthermore, the majority of studies demonstrating efficacy of subcutaneous immunotherapy involved single allergen immunotherapy, whereas most children with severe asthma are polysensitized( 3,134$)$. In addition, allergen immunotherapy should not be initiated in patients with asthma that is not stable to 
pharmacotherapy(132), a situation which is more common amongst children with severe asthma.

Emerging Therapies-Other novel medications for asthma have been studied in adults and most are considered experimental in children.

Long-acting anti-cholinergics: Tiotropium is an inhaled long-acting anti-cholinergic agent that is approved by the U.S. Food and Drug Administration for the treatment of chronic obstructive pulmonary disease in adults. Although tiotropium is not currently approved for use in asthma or for use in children, studies have suggested that it may have benefit in the management of persistent asthma in adult populations. A large, multi-center trial in young adults found that the addition of tiotropium to an ICS was superior to doubling the dose of the ICS as evidenced by morning peak expiratory flow(135) and equivalent to those observed with salmeterol(135). Other studies have observed similar findings $(136,137)$. Two replicate, randomized, controlled trials involving 912 adults with poorly controlled asthma despite the use of ICS and LABAs, the addition of tiotropium significantly increased the time to the first severe exacerbation and improved lung function(138). While additional studies are needed, early evidence suggests that younger patients with higher cholinergic tone (i.e., lower resting heart rate) and a higher degree of bronchodilator reversibility may derive the most benefit from tiotropium when added on to ICS(139).

Immunomodulators: Omalizumab is an injectable recombinant humanized IgG1 monoclonal anti-IgE antibody that is given every $2-4$ weeks in patients with chronic allergic asthma with at least one positive skin test and an elevated serum IgE level. In children aged 6-12 years, two randomized, placebo-controlled studies with moderate-to-severe asthma reduced ICS doses and the number of exacerbations(140, 141). Furthermore, omalizumab significantly reduced the rate of clinically significant asthma exacerbations, severe exacerbations and emergency visits in teenagers and in adults with poorly controlled severe persistent asthma(142). Omalizumab may be most effective in children with allergic sensitization and asthma who require high doses of ICS and experience frequent exacerbations. In 419 inner-city children and young-adults with asthma (53-55\% receiving step $4-6$ therapy per NAEPP/EPR3 Guidelines), treatment with omalizumab added to a regimen of guidelines-based therapy further improved asthma control, nearly eliminated seasonal peaks in exacerbations, and reduced the need for additional medications to control asthma(143). These positive findings occurred in the context of reductions in doses of ICS and LABAs. Drawbacks include limitations due weight and serum IgE level requirements and the expense of treatment. Long-term side effects have not been evaluated in children. At the present time, omalizumab is not FDA-approved for children under 12 years of age. Based upon the emerging evidence supporting the recommendation for use of omalizumab in children, the ERS/ATS Severe Asthma Guidelines also suggest that treatment response be globally assessed and if a patient does not respond within four months of initiating therapy, further administration is unlikely to be beneficial(27).

In addition to omalizumab, several other immunomodulatory monoclonal antibodies are currently undergoing clinical trials in adults. Agents that target Th2-driven airway inflammation have attracted considerable attention. The recombinant IL-4 variant pitakinra. 
which interferes with the action of both IL-4 and IL-13, has been shown to reduce exacerbations among patients with eosinophilia(144). Dupilumab, a fully humanized antibody to the alpha-subunit of the IL-4 receptor, reduced asthma exacerbations, improved lung function, and reduced markers of Th2 inflammation among adults with moderatesevere asthma with elevated levels of eosinophils in either blood or sputum being treated with ICS and LABA(145). Lebrikizumab, a monoclonal antibody against IL-13, resulted in improved lung function among adults with asthma inadequately controlled by ICS (median dose $500 \mathrm{mcg} /$ day), and this effect was most evident among participants with high pretreatment levels of serum periostin(146). Finally, several trials have been conducted with monoclonal antibodies directed against IL-5, mepolizumab and resilizumab with effects predominantly on reduction of exacerbations without having a large impact on other relevant asthma-related outcomes.(147-149). Overall, while these biologic immunomodulators appear to have favorable effects in adults with asthma, none have been directly and specifically studied in children with severe asthma.

Immunosuppressants: Meta-analyses studying the efficacy of potentially corticosteroidsparing immunosuppressant therapy such as cyclopsorine A, methotrexate or azathioprine have not found clear evidence to support their general use in the treatment of severe asthma in children(150). Indeed, the recent ATS/ERS guidelines on severe asthma recommend that these agents not be used in children with severe asthma due to low quality of available evidence and a high risk of side effects(27).

Bronchial Thermoplasty: Bronchial thermoplasty involves the delivery of radiofrequencygenerated heat to the airway tree via a catheter inserted into a flexible bronchoscope. Bronchial thermoplasty is not currently FDA-approved for children or adolescents, but has been used in selected populations of adults with moderate-to-severe persistent asthma despite treatment with ICS and long-acting beta agonists. In the original studies, bronchial thermoplasty was associated with improvements in asthma control(151-153) and asthmarelated quality of life(154). However, a recent meta-analysis suggests that the procedure provides modest clinical benefit in quality of life and rates of exacerbations, although the quality of life findings are subject to bias given the lack of sham treatment arms in several studies(155). Furthermore, despite the availability and reassurance of long-term (i.e., 5-year) safety studies(156-158), the ATS/ERS 2014 guidelines on severe asthma recommend that bronchial thermoplasty only be performed in adults with severe asthma in the context of an Institutional Review Board-approved study(27).

Antimicrobials: Chronic infections may contribute to severe asthma. In adults, infection with Chlamydia pneumoniae and Mycoplasma pneumoniae has been lower lung function and increased airways hyperresponsiveness which has improved with macrolide therapy $(159,160)$. A trial in children with moderate-to-severe persistent did not find that the addition of azithromycin to an ICS was corticosteroid sparing. However, it should be noted that the trial was terminated early due to randomization failure due to inadequate adherence to study medication and improved asthma control under close medical supervision(161). Macrolide antibiotics have also been suggested for the treatment of childhood asthma associated with persistent neutrophilic inflammation(162). ATS/ERS 2014 guidelines on 
severe asthma recommend against routine use of macrolide therapy for children(27). Case reports have described children who develop severe asthma in the presence of fungal infections(163).The ATS/ERS 2014 guidelines also recommend that antifungal agents only be used in children if a detailed specialist evaluation is suggestive of allergic bronchopulmonary aspergillosis.

\section{Patient Education and Lifestyle Modification}

Both national and international asthma guidelines strongly recommend structured asthma education(41, 97). A good dialogue between patients and care providers is encouraged. Moreover, patients may have different ideas from doctors regarding symptom control as well as strong lay beliefs about medications and their side effects, which should be addressed. A balance between the degree of asthma control, medication side effects, and quality of life should be established. A structured educational program improves adherence from less than $20 \%$ of patients given a prescription alone to approximately $70 \%$ of patients who receive both a prescription and a structured education plan, even after 6 months(164). Providing education, environmental control, adherence with treatment and proper use of inhalers, and using an adequate asthma control assessment represent key factors to help reduce the severity of asthma $(165,166)$. Smoking cessation programs for the parents or child are also widely recommended $(41,97)$. Tobacco smoke exposure has been associated with a higher incidence of upper respiratory tract infections and prevalence of asthma, and a greater severity of exacerbations in children(42). However, the impact of this exposure on the therapeutic response has not been documented. Psychosocial factors such as depression and anxiety and asthma-specific quality of life have effects on adherence(98), are common in adolescents with persistent asthma, demonstrate variable prevalence across different race/ ethnicities, and are related to increased asthma morbidity, healthcare use, and school absenteeism(167). Thus, evaluation of asthma-related quality of life and psychosocial stressors and intervention are important $(168,169)$. As with most chronic childhood diseases, adopting healthy lifestyle programs to address the poor diet, inactivity, and sedentary lifestyle of the child with asthma can be important in attaining adequate asthma control(9).

\section{Conclusion}

Although knowledge of asthma and its associated mechanisms has increased substantially over the past decades, significant gaps remain about the determinants of severe asthma in children. It is not clear how the different phenotypes of severe asthma change across time, nor is it clear if these changes are modifiable with appropriate therapy. It is important to identify and address the influences that make asthma difficult to control including reviewing the diagnosis and the removal of causal or aggravating factors. Better definition of the phenotypes and better targeting of therapy based upon individual patient phenotypes is likely to facilitate improved individualized and precision asthma treatment in the future. Finally, trials of novel therapeutic strategies for severe asthma in childhood populations are essential to provide population-specific evidence to guide the children with severe asthma rather than ongoing reliance on extrapolation from studies conducted in adults. 


\section{Abbreviations}
ATS
American Thoracic Society
BMI
Body mass index
ERS
European Respiratory Society
GERD
Gastroesophageal reflux
EGD
Esophagogastroduodenoscopy
FEF25-75
Forced expiratory flow $25-75 \%$
FENO
Exhaled nitric oxide
FEV1
Forced expiratory volume in 1 second
FVC
Forced vital capacity
GINA
Global Initiative on Asthma
ICS
Inhaled corticosteroids
IgE
Immunoglobulin $\mathrm{E}$
NAEPP
National Asthma Education and Prevention Program

\section{References}

1. Centers for Disease Control and Prevention (CDC). Vital signs: asthma prevalence, disease characteristics, and self-management education: United States, 2001-2009. MMWR Morb Mortal Wkly Rep. 2011; 60(17):547-52. [PubMed: 21544044]

2. Bossley CJ, Saglani S, Kavanagh C, Payne DN, Wilson N, Tsartsali L, et al. Corticosteroid responsiveness and clinical characteristics in childhood difficult asthma. Eur Respir J. 2009 Nov; 34(5):1052-9. Epub 2009/06/23. eng. [PubMed: 19541710]

3. Fitzpatrick AM, Gaston BM, Erzurum SC, Teague WG. Features of severe asthma in school-age children: Atopy and increased exhaled nitric oxide. J Allergy Clin Immunol. 2006 Dec; 118(6): 1218-25. Epub 2006/12/13. eng. [PubMed: 17157650]

4. Lang A, Carlsen KH, Haaland G, Devulapalli CS, Munthe-Kaas M, Mowinckel P, et al. Severe asthma in childhood: assessed in 10 year olds in a birth cohort study. Allergy. 2008 Aug; 63(8): 1054-60. [PubMed: 18691307]

5. Godard P, Chanez P, Siraudin L, Nicoloyannis N, Duru G. Costs of asthma are correlated with severity: a 1-yr prospective study. Eur Respir J. 2002 Jan; 19(1):61-7. Epub 2002/02/15. eng. [PubMed: 11843329]

6. Smith DH, Malone DC, Lawson KA, Okamoto LJ, Battista C, Saunders WB. A national estimate of the economic costs of asthma. Am J Respir Crit Care Med. 1997 Sep; 156(3 Pt 1):787-93. Epub 1997/10/06. eng. [PubMed: 9309994]

7. Bush A, Hedlin G, Carlsen KH, de Benedictis F, Lodrup-Carlsen K, Wilson N. Severe childhood asthma: a common international approach? Lancet. 2008 Sep 20; 372(9643):1019-21. Epub 2008/09/23. eng. [PubMed: 18805316]

8. Fitzpatrick AM, Teague WG. Severe Asthma in Children: Insights from the National Heart, Lung, and Blood Institute's Severe Asthma Research Program. Pediatr Allergy Immunol Pulmonol. 2010 Jun; 23(2):131-8. Epub 2011/07/16. Eng. [PubMed: 21761006]

9. Paton JY. Severe Asthma in Children. Symposium: Respiratory Medicine. Paediatric and Child Health. 2007; 17(5):180-7. 
10. Galant SP, Morphew T, Amaro S, Liao O. Current asthma guidelines may not identify young children who have experienced significant morbidity. Pediatrics. 2006 Apr; 117(4):1038-45. Epub 2006/04/06. eng. [PubMed: 16585297]

11. Gelfand EW, Kraft M. The importance and features of the distal airways in children and adults. J Allergy Clin Immunol. 2009 Dec; 124(6 Suppl):S84-7. Epub 2010/01/09. eng. [PubMed: 19962041]

12. Drazen JM, O'Byrne PM. Risks of long-acting beta-agonists in achieving asthma control. N Engl J Med. 2009; 360(16):1671-2. [PubMed: 19369675]

13. Bacharier LB, Boner A, Carlsen KH, Eigenmann PA, Frischer T, Gotz M, et al. Diagnosis and treatment of asthma in childhood: a PRACTALL consensus report. Allergy. 2008 Jan; 63(1):5-34. [PubMed: 18053013]

14. Jenkins HA, Cherniack R, Szefler SJ, Covar R, Gelfand EW, Spahn JD. A comparison of the clinical characteristics of children and adults with severe asthma. Chest. 2003; 124(4):1318-24. [PubMed: 14555561]

15. Bacharier LB, Strunk RC, Mauger D, White D, Lemanske RF Jr, Sorkness CA. Classifying asthma severity in children: mismatch between symptoms, medication use, and lung function. Am J Respir Crit Care Med. 2004 Aug 15; 170(4):426-32. Epub 2004/06/03. eng. [PubMed: 15172893]

16. Spahn JD, Cherniack R, Paull K, Gelfand EW. Is forced expiratory volume in one second the best measure of severity in childhood asthma? Am J Respir Crit Care Med. 2004 Apr 1; 169(7):784-6. Epub 2004/02/03. eng. [PubMed: 14754761]

17. Hogg JC, Macklem PT, Thurlbeck WM. Site and nature of airway obstruction in chronic obstructive lung disease. N Engl J Med. 1968 Jun 20; 278(25):1355-60. Epub 1968/06/20. eng. [PubMed: 5650164]

18. Spahn JD, Covar RA, Jain N, Gleason M, Shimamoto R, Szefler SJ, et al. Effect of montelukast on peripheral airflow obstruction in children with asthma. Ann Allergy Asthma Immunol. 2006 Apr; 96(4):541-9. Epub 2006/05/10. eng. [PubMed: 16680924]

19. Sorkness RL, Teague WG, Penugonda M, Fitzpatrick AM. Sex dependence of airflow limitation and air trapping in children with severe asthma. J Allergy Clin Immunol. 2011 Apr; 127(4):10734. Epub 2011/02/12. eng. [PubMed: 21310476]

20. Martinez FD, Wright AL, Taussig LM, Holberg CJ, Halonen M, Morgan WJ. Asthma and wheezing in the first six years of life. The Group Health Medical Associates. N Engl J Med. 1995 Jan 19; 332(3):133-8. [PubMed: 7800004]

21. Strunk RC, Weiss ST, Yates KP, Tonascia J, Zeiger RS, Szefler SJ. Mild to moderate asthma affects lung growth in children and adolescents. J Allergy Clin Immunol. 2006; 118(5):1040-7. [PubMed: 17088127]

22. Bhavsar P, Hew M, Khorasani N, Torrego A, Barnes PJ, Adcock I, et al. Relative corticosteroid insensitivity of alveolar macrophages in severe asthma compared with non-severe asthma. Thorax. 2008 Sep; 63(9):784-90. Epub 2008/05/22. eng. [PubMed: 18492738]

23. Hew M, Bhavsar P, Torrego A, Meah S, Khorasani N, Barnes PJ, et al. Relative corticosteroid insensitivity of peripheral blood mononuclear cells in severe asthma. Am J Respir Crit Care Med. 2006 Jul 15; 174(2):134-41. Epub 2006/04/15. eng. [PubMed: 16614347]

24. McKenzie SA, Bush A. Difficult asthma in children. Thorax. 2002 Oct; 57(10):915-6. Epub 2002/09/27. eng. [PubMed: 12324681]

25. Meyers DA, Postma DS, Stine OC, Koppelman GH, Ampleford EJ, Jongepier H, et al. Genome screen for asthma and bronchial hyperresponsiveness: interactions with passive smoke exposure. $\mathrm{J}$ Allergy Clin Immunol. 2005 Jun; 115(6):1169-75. Epub 2005/06/09. eng. [PubMed: 15940130]

26. ten Brinke A, Ouwerkerk ME, Zwinderman AH, Spinhoven P, Bel EH. Psychopathology in patients with severe asthma is associated with increased health care utilization. Am J Respir Crit Care Med. 2001 Apr; 163(5):1093-6. Epub 2001/04/24. eng. [PubMed: 11316641]

27. Chung KF, Wenzel SE, Brozek JL, Bush A, Castro M, Sterk PJ, et al. International ERS/ATS guidelines on definition, evaluation and treatment of severe asthma. Eur Respir J. 2014 Feb; 43(2): 343-73. [PubMed: 24337046]

28. Baker KM, Brand DA, Hen J Jr. Classifying asthma: disagreement among specialists. Chest. 2003; 124(6):2156-63. [PubMed: 14665495] 
29. Stern DA, Morgan WJ, Halonen M, Wright AL, Martinez FD. Wheezing and bronchial hyperresponsiveness in early childhood as predictors of newly diagnosed asthma in early adulthood: a longitudinal birth-cohort study. Lancet. 2008; 372(9643):1058-64. [PubMed: 18805334]

30. Haland G, Carlsen KC, Sandvik L, Devulapalli CS, Munthe-Kaas MC, Pettersen M, et al. Reduced lung function at birth and the risk of asthma at 10 years of age. N Engl J Med. 2006 Oct 19; 355(16):1682-9. Epub 2006/10/20. eng. [PubMed: 17050892]

31. Stern DA, Morgan WJ, Wright AL, Guerra S, Martinez FD. Poor airway function in early infancy and lung function by age 22 years: a non-selective longitudinal cohort study. Lancet. 2007; 370(9589):758-64. [PubMed: 17765525]

32. Chipps BE, Szefler SJ, Simons FE, Haselkorn T, Mink DR, Deniz Y, et al. Demographic and clinical characteristics of children and adolescents with severe or difficult-to-treat asthma. J Allergy Clin Immunol. 2007 May; 119(5):1156-63. Epub 2007/04/03. eng. [PubMed: 17397912]

33. Payne DN, Wilson NM, James A, Hablas H, Agrafioti C, Bush A. Evidence for different subgroups of difficult asthma in children. Thorax. 2001 May; 56(5):345-50. Epub 2001/04/20. eng. [PubMed: 11312401]

34. Zeiger RS, Chipps BE, Haselkorn T, Rasouliyan L, Simons FE, Fish JE. Comparison of asthma exacerbations in pediatric and adult patients with severe or difficult-to-treat asthma. J Allergy Clin Immunol. 2009 Nov; 124(5):1106-8. Epub 2009/10/06. eng. [PubMed: 19800677]

35. Rasmussen F, Taylor DR, Flannery EM, Cowan JO, Greene JM, Herbison GP, et al. Risk factors for airway remodeling in asthma manifested by a low postbronchodilator FEV1/vital capacity ratio: a longitudinal population study from childhood to adulthood. Am J Respir Crit Care Med. 2002 Jun 1; 165(11):1480-8. Epub 2002/06/05. eng. [PubMed: 12045120]

36. The Childhood Asthma Management Program Research Group. Long-term effects of budesonide or nedocromil in children with asthma. N Engl J Med. 2000 Oct 12; 343(15):1054-63. [PubMed: 11027739]

37. Covar RA, Strunk R, Zeiger RS, Wilson LA, Liu AH, Weiss S, et al. Predictors of remitting, periodic, and persistent childhood asthma. J Allergy Clin Immunol. 2010 Feb; 125(2):359-66. e3. Epub 2010/02/18. eng. [PubMed: 20159245]

38. Spycher BD, Silverman M, Brooke AM, Minder CE, Kuehni CE. Distinguishing phenotypes of childhood wheeze and cough using latent class analysis. Eur Respir J. 2008 May; 31(5):974-81. Epub 2008/01/25. eng. [PubMed: 18216047]

39. Van Wonderen KE, Van Der Mark LB, Mohrs J, Bindels PJ, Van Aalderen WM, Ter Riet G. Different definitions in childhood asthma: how dependable is the dependent variable? Eur Respir J. 2010 Jul; 36(1):48-56. [PubMed: 20032011]

40. National Asthma Education and Prevention Program. Expert Panel Report 3: guidelines for the diagnosis and management of asthma: clinical practice guidelines. Bethesda (MD): NIH/National Heart, Lung, and Blood Institute; 2007 Aug. p. 4051

41. Global Strategy for Asthma Management and Prevention. Global Initiative for Asthma (GINA). 2006. Available from: http:Ihttp://www.ginasthma.org

42. Hussell T, Openshaw PJM. IL-12-activated NK cells reduce lung eosinophilia to the attachment protein of respiratory syncytial virus but do not enhance the severity of illness in CD8 T cellimmunodeficient conditions. J Immunol. 2000; 165:7109-15. [PubMed: 11120841]

43. Bousquet J, Mantzouranis E, Cruz AA, Ait-Khaled N, Baena-Cagnani CE, Bleecker ER, et al. Uniform definition of asthma severity, control, and exacerbations: document presented for the World Health Organization Consultation on Severe Asthma. J Allergy Clin Immunol. 2010 Nov; 126(5):926-38. Epub 2010/10/12. eng. [PubMed: 20926125]

44. Wenzel SE, Schwartz LB, Langmack EL, Halliday JL, Trudeau JB, Gibbs RL, et al. Evidence that severe asthma can be divided pathologically into two inflammatory subtypes with distinct physiologic and clinical characteristics. Am J Respir Crit Care Med. 1999 Sep; 160(3):1001-8. Epub 1999/09/03. eng. [PubMed: 10471631]

45. Wenzel SE. Asthma: defining of the persistent adult phenotypes. Lancet. 2006; 368(9537):804-13. [PubMed: 16935691]

46. Payne D, Bush A. Phenotype-specific treatment of difficult asthma in children. Paediatr Respir Rev. 2004 Jun; 5(2):116-23. Epub 2004/05/12. eng. [PubMed: 15135121] 
47. Gibson PG, Simpson JL, Saltos N. Heterogeneity of airway inflammation in persistent asthma : evidence of neutrophilic inflammation and increased sputum interleukin-8. Chest. 2001 May; 119(5):1329-36. Epub 2001/05/12. eng. [PubMed: 11348936]

48. Gibson PG, Henry RL, Thomas P. Noninvasive assessment of airway inflammation in children: induced sputum, exhaled nitric oxide, and breath condensate. Eur Respir J. 2000 Nov; 16(5):100815. Epub 2001/01/12. eng. [PubMed: 11153569]

49. Gibson PG, Simpson JL, Hankin R, Powell H, Henry RL. Relationship between induced sputum eosinophils and the clinical pattern of childhood asthma. Thorax. 2003 Feb; 58(2):116-21. Epub 2003/01/30. eng. [PubMed: 12554891]

50. Bush A. How early do airway inflammation and remodeling occur? Allergol Int. 2008 Mar; 57(1): 11-9. Epub 2008/01/23. eng. [PubMed: 18209503]

51. He XY, Simpson JL, Wang F. Inflammatory phenotypes in stable and acute childhood asthma. Paediatr Respir Rev. 2011 Sep; 12(3):165-9. Epub 2011/07/05. eng. [PubMed: 21722844]

52. Zacharasiewicz A, Wilson N, Lex C, Erin EM, Li AM, Hansel T, et al. Clinical use of noninvasive measurements of airway inflammation in steroid reduction in children. Am J Respir Crit Care Med. 2005 May 15; 171(10):1077-82. Epub 2005/02/15. eng. [PubMed: 15709050]

53. Green RH, Brightling CE, McKenna S, Hargadon B, Parker D, Bradding P, et al. Asthma exacerbations and sputum eosinophil counts: a randomised controlled trial. Lancet. 2002; 360(9347):1715-21. [PubMed: 12480423]

54. Fleming L, Tsartsali L, Wilson N, Regamey N, Bush A. Sputum inflammatory phenotypes are not stable in children with asthma. Thorax. 2012 Aug; 67(8):675-81. [PubMed: 22379070]

55. Payne DN, Adcock IM, Wilson NM, Oates T, Scallan M, Bush A. Relationship between exhaled nitric oxide and mucosal eosinophilic inflammation in children with difficult asthma, after treatment with oral prednisolone. Am J Respir Crit Care Med. 2001 Oct 15; 164(8 Pt 1):1376-81. Epub 2001/11/13. eng. [PubMed: 11704581]

56. Bossley CJ, Fleming L, Gupta A, Regamey N, Frith J, Oates T, et al. Pediatric severe asthma is characterized by eosinophilia and remodeling without $\mathrm{T}(\mathrm{H}) 2$ cytokines. J Allergy Clin Immunol. 2012 Apr; 129(4):974-82. e13. Epub 2012/03/06. eng. [PubMed: 22385633]

57. Douwes J, Gibson P, Pekkanen J, Pearce N. Non-eosinophilic asthma: importance and possible mechanisms. Thorax. 2002 Jul; 57(7):643-8. Epub 2002/07/04. eng. [PubMed: 12096210]

58. Chaudhuri R, Livingston E, McMahon AD, Thomson L, Borland W, Thomson NC. Cigarette smoking impairs the therapeutic response to oral corticosteroids in chronic asthma. Am J Respir Crit Care Med. 2003 Dec 1; 168(11):1308-11. Epub 2003/08/02. eng. [PubMed: 12893649]

59. Bacharier LB, Guilbert TW, Zeiger RS, Strunk RC, Morgan WJ, Lemanske RF Jr, et al. Patient characteristics associated with improved outcomes with use of an inhaled corticosteroid in preschool children at risk for asthma. J Allergy Clin Immunol. 2009 May; 123(5):1077-82. 82, e1-5. Epub 2009/02/24. eng. [PubMed: 19230959]

60. Payne DN, Qiu Y, Zhu J, Peachey L, Scallan M, Bush A, et al. Airway inflammation in children with difficult asthma: relationships with airflow limitation and persistent symptoms. Thorax. 2004; 59(10):862-9. [PubMed: 15454652]

61. Oborne J, Mortimer K, Hubbard RB, Tattersfield AE, Harrison TW. Quadrupling the dose of inhaled corticosteroid to prevent asthma exacerbations: a randomized, double-blind, placebocontrolled, parallel-group clinical trial. Am J Respir Crit Care Med. 2009; 180(7):598-602. [PubMed: 19590019]

62. Lex C, Payne DN, Zacharasiewicz A, Li AM, Wilson NM, Hansel TT, et al. Sputum induction in children with difficult asthma: safety, feasibility, and inflammatory cell pattern. Pediatr Pulmonol. 2005 Apr; 39(4):318-24. Epub 2005/01/29. eng. [PubMed: 15678506]

63. Fitzpatrick AM, Higgins M, Holguin F, Brown LA, Teague WG. The molecular phenotype of severe asthma in children. J Allergy Clin Immunol. 2010 Apr; 125(4):851-7. e18. Epub 2010/04/08. eng. [PubMed: 20371397]

64. Fitzpatrick AM, Teague WG, Meyers DA, Peters SP, Li X, Li H, et al. Heterogeneity of severe asthma in childhood: confirmation by cluster analysis of children in the National Institutes of Health/National Heart, Lung, and Blood Institute Severe Asthma Research Program. J Allergy Clin Immunol. 2011 Feb; 127(2):382-9. e1-13. Epub 2011/01/05. eng. [PubMed: 21195471] 
65. Just J, Saint-Pierre P, Gouvis-Echraghi R, Laoudi Y, Roufai L, Momas I, et al. Childhood allergic asthma is not a single phenotype. J Pediatr. 2014 Apr; 164(4):815-20. [PubMed: 24412137]

66. Just J, Gouvis-Echraghi R, Rouve S, Wanin S, Moreau D, Annesi-Maesano I. Two novel, severe asthma phenotypes identified during childhood using a clustering approach. Eur Respir J. 2012 Jul; 40(1):55-60. [PubMed: 22267763]

67. Schatz M, Hsu JW, Zeiger RS, Chen W, Dorenbaum A, Chipps BE, et al. Phenotypes determined by cluster analysis in severe or difficult-to-treat asthma. J Allergy Clin Immunol. 2014 Jun; 133(6):1549-56. [PubMed: 24315502]

68. Fitzpatrick AM, Park Y, Brown LA, Jones DP. Children with severe asthma have unique oxidative stress-associated metabolomic profiles. J Allergy Clin Immunol. 2014 Jan; 133(1):258-61. e1-8. [PubMed: 24369802]

69. Brown SD, Baxter KM, Stephenson ST, Esper AM, Brown LA, Fitzpatrick AM. Airway TGFbeta1 and oxidant stress in children with severe asthma: association with airflow limitation. $\mathbf{J}$ Allergy Clin Immunol. 2012 Feb; 129(2):388-96. 96 e1-8. Epub 2011/12/31. eng. [PubMed: 22206775]

70. Fitzpatrick AM, Teague WG, Burwell L, Brown MS, Brown LA, Program NNSAR. Glutathione oxidation is associated with airway macrophage functional impairment in children with severe asthma. Pediatr Res. 2011 Feb; 69(2):154-9. [PubMed: 20975618]

71. Fitzpatrick AM, Stephenson ST, Hadley GR, Burwell L, Penugonda M, Simon DM, et al. Thiol redox disturbances in children with severe asthma are associated with posttranslational modification of the transcription factor nuclear factor (erythroid-derived 2)-like 2. J Allergy Clin Immunol. 2011 Jun; 127(6):1604-11. [PubMed: 21514635]

72. Fitzpatrick AM, Brown LA, Holguin F, Teague WG. National Institutes of Health/National Heart L, Blood Institute Severe Asthma Research P. Levels of nitric oxide oxidation products are increased in the epithelial lining fluid of children with persistent asthma. J Allergy Clin Immunol. 2009 Nov; 124(5):990-6. e1-9. [PubMed: 19895987]

73. Fitzpatrick AM, Teague WG, Holguin F, Yeh M, Brown LA. Severe Asthma Research P. Airway glutathione homeostasis is altered in children with severe asthma: evidence for oxidant stress. J Allergy Clin Immunol. 2009 Jan; 123(1):146-52. e8. Epub 2009/01/10. eng. [PubMed: 19130935]

74. Wan YI, Shrine NR, Soler Artigas M, Wain LV, Blakey JD, Moffatt MF, et al. Genome-wide association study to identify genetic determinants of severe asthma. Thorax. 2012 Sep; 67(9):7628. [PubMed: 22561531]

75. Hancock DB, Eijgelsheim M, Wilk JB, Gharib SA, Loehr LR, Marciante KD, et al. Meta-analyses of genome-wide association studies identify multiple loci associated with pulmonary function. Nature genetics. 2010 Jan; 42(1):45-52. [PubMed: 20010835]

76. Repapi E, Sayers I, Wain LV, Burton PR, Johnson T, Obeidat M, et al. Genome-wide association study identifies five loci associated with lung function. Nat Genet. 2010 Jan; 42(1):36-44. [PubMed: 20010834]

77. Li X, Howard TD, Moore WC, Ampleford EJ, Li H, Busse WW, et al. Importance of hedgehog interacting protein and other lung function genes in asthma. J Allergy Clin Immunol. 2011 Jun; 127(6):1457-65. Epub 2011/03/15. eng. [PubMed: 21397937]

78. Li X, Hawkins GA, Ampleford EJ, Moore WC, Li H, Hastie AT, et al. Genome-wide association study identifies TH1 pathway genes associated with lung function in asthmatic patients. J Allergy Clin Immunol. 2013 Aug; 132(2):313-20. e15. [PubMed: 23541324]

79. Tantisira KG, Lake S, Silverman ES, Palmer LJ, Lazarus R, Silverman EK, et al. Corticosteroid pharmacogenetics: association of sequence variants in CRHR1 with improved lung function in asthmatics treated with inhaled corticosteroids. Hum Mol Genet. 2004 Jul 1; 13(13):1353-9. Epub 2004/05/07. eng. [PubMed: 15128701]

80. Tantisira KG, Hwang ES, Raby BA, Silverman ES, Lake SL, Richter BG, et al. TBX21: a functional variant predicts improvement in asthma with the use of inhaled corticosteroids. Proc Natl Acad Sci U S A. 2004 Dec 28; 101(52):18099-104. Epub 2004/12/18. eng. [PubMed: 15604153] 
81. Tantisira KG, Silverman ES, Mariani TJ, Xu J, Richter BG, Klanderman BJ, et al. FCER2: a pharmacogenetic basis for severe exacerbations in children with asthma. J Allergy Clin Immunol. 2007 Dec; 120(6):1285-91. Epub 2007/11/06. eng. [PubMed: 17980418]

82. Kamada AK, Spahn JD, Surs W, Brown E, Leung DY, Szefler SJ. Coexistence of glucocorticoid receptor and pharmacokinetic abnormalities: factors that contribute to a poor response to treatment with glucocorticoids in children with asthma. J Pediatr. 1994 Jun; 124(6):984-6. [PubMed: 8201491]

83. Goleva E, Jackson LP, Gleason M, Leung DY. Usefulness of PBMCs to predict clinical response to corticosteroids in asthmatic patients. J Allergy Clin Immunol. 2012 Mar; 129(3):687-93. e1. Epub 2012/01/13. eng. [PubMed: 22236730]

84. Haldar P, Pavord ID, Shaw DE, Berry MA, Thomas M, Brightling CE, et al. Cluster analysis and clinical asthma phenotypes. Am J Respir Crit Care Med. 2008 Aug 1; 178(3):218-24. Epub 2008/05/16. eng. [PubMed: 18480428]

85. Sutherland ER, Goleva E, Strand M, Beuther DA, Leung DY. Body mass and glucocorticoid response in asthma. Am J Respir Crit Care Med. 2008 Oct 1; 178(7):682-7. Epub 2008/07/19. eng. [PubMed: 18635892]

86. Havemann BD, Henderson CA, El-Serag HB. The association between gastro-oesophageal reflux disease and asthma: a systematic review. Gut. 2007 Dec; 56(12):1654-64. Epub 2007/08/08. eng. [PubMed: 17682001]

87. Thakkar K, Boatright RO, Gilger MA, El-Serag HB. Gastroesophageal reflux and asthma in children: a systematic review. Pediatrics. 2010 Apr; 125(4):e925-30. Epub 2010/03/31. eng. [PubMed: 20351005]

88. Holbrook JT, Wise RA, Gold BD, Blake K, Brown ED, Castro M, et al. Lansoprazole for children with poorly controlled asthma: a randomized controlled trial. JAMA : the journal of the American Medical Association. 2012 Jan 25; 307(4):373-81. Epub 2012/01/26. eng. [PubMed: 22274684]

89. Bush A, Saglani S. Management of severe asthma in children. Lancet. 2010 Sep 4; 376(9743):81425. Epub 2010/09/08. eng. [PubMed: 20816548]

90. Blake K, Teague WG. Gastroesophageal reflux disease and childhood asthma. Current opinion in pulmonary medicine. 2013 Jan; 19(1):24-9. [PubMed: 23197288]

91. Sundberg R, Toren K, Hoglund D, Aberg N, Brisman J. Nasal symptoms are associated with school performance in adolescents. J Adolesc Health. 2007 Jun; 40(6):581-3. Epub 2007/05/29. eng. [PubMed: 17531771]

92. Bousquet PJ, Combescure C, Klossek JM, Daures JP, Bousquet J. Change in visual analog scale score in a pragmatic randomized cluster trial of allergic rhinitis. J Allergy Clin Immunol. 2009 Jun; 123(6):1349-54. Epub 2009/04/17. eng. [PubMed: 19368963]

93. Rollin M, Seymour K, Hariri M, Harcourt J. Rhinosinusitis, symptomatology \& absence of polyposis in children with primary ciliary dyskinesia. Rhinology. 2009 Mar; 47(1):75-8. Epub 2009/04/23. eng. [PubMed: 19382500]

94. Gimenez LM, Zafra H. Vocal cord dysfunction: an update. Ann Allergy Asthma Immunol. Apr; 106(4):267-74. quiz 75. Epub 2011/04/05. eng. [PubMed: 21457874]

95. Seear M, Wensley D, West N. How accurate is the diagnosis of exercise induced asthma among Vancouver schoolchildren? Arch Dis Child. 2005 Sep; 90(9):898-902. Epub 2005/04/28. eng. [PubMed: 15855180]

96. Male I, Richter H, Seddon P. Children's perception of breathlessness in acute asthma. Arch Dis Child. 2000 Oct; 83(4):325-9. Epub 2000/09/22. eng. [PubMed: 10999869]

97. Expert Panel Report 3 (EPR-3): Guidelines for the Diagnosis and Management of AsthmaSummary Report 2007. J Allergy Clin Immunol. 2007 Nov; 120(5 Suppl):S94-138. Epub 2007/12/06. eng. [PubMed: 17983880]

98. Wright RJ, Rodriguez M, Cohen S. Review of psychosocial stress and asthma: an integrated biopsychosocial approach. Thorax. 1998 Dec; 53(12):1066-74. Epub 1999/04/09. eng. [PubMed: 10195081]

99. Holgate ST, Polosa R. The mechanisms, diagnosis, and management of severe asthma in adults. Lancet. 2006; 368(9537):780-93. [PubMed: 16935689] 
100. Robinson DS, Campbell DA, Durham SR, Pfeffer J, Barnes PJ, Chung KF. Systematic assessment of difficult-to-treat asthma. Eur Respir J. 2003 Sep; 22(3):478-83. Epub 2003/10/01. eng. [PubMed: 14516138]

101. Saglani S, Nicholson AG, Scallan M, Balfour-Lynn I, Rosenthal M, Payne DN, et al. Investigation of young children with severe recurrent wheeze: any clinical benefit? Eur Respir J. 2006 Jan; 27(1):29-35. Epub 2006/01/03. eng. [PubMed: 16387932]

102. Schatz M, Sorkness CA, Li JT, Marcus P, Murray JJ, Nathan RA, et al. Asthma Control Test: reliability, validity, and responsiveness in patients not previously followed by asthma specialists. J Allergy Clin Immunol. 2006 Mar; 117(3):549-56. Epub 2006/03/09. eng. [PubMed: 16522452]

103. Bracken M, Fleming L, Hall P, Van Stiphout N, Bossley C, Biggart E, et al. The importance of nurse-led home visits in the assessment of children with problematic asthma. Arch Dis Child. 2009 Oct; 94(10):780-4. Epub 2009/06/24. eng. [PubMed: 19546102]

104. Bisgaard H, Hermansen MN, Loland L, Halkjaer LB, Buchvald F. Intermittent inhaled corticosteroids in infants with episodic wheezing. N Engl J Med. 2006; 354(19):1998-2005. [PubMed: 16687712]

105. Guilbert TW, Morgan WJ, Zeiger RS, Mauger DT, Boehmer SJ, Szefler SJ, et al. Long-term inhaled corticosteroids in preschool children at high risk for asthma. N Engl J Med. 2006; 354(19):1985-97. [PubMed: 16687711]

106. Murray CS, Woodcock A, Langley SJ, Morris J, Custovic A. Secondary prevention of asthma by the use of Inhaled fluticasone propionate in Wheezy INfants (IFWIN): double-blind, randomised, controlled study. Lancet. 2006; 368(9537):754-62. [PubMed: 16935686]

107. O’Byrne PM, Pedersen S, Lamm CJ, Tan WC, Busse WW. Severe exacerbations and decline in lung function in asthma. Am J Respir Crit Care Med. 2009 Jan 1; 179(1):19-24. Epub 2008/11/08. eng. [PubMed: 18990678]

108. Brutsche MH, Brutsche IC, Munawar M, Langley SJ, Masterson CM, Daley-Yates PT, et al. Comparison of pharmacokinetics and systemic effects of inhaled fluticasone propionate in patients with asthma and healthy volunteers: a randomised crossover study. Lancet. 2000 Aug 12; 356(9229):556-61. Epub 2000/08/19. eng. [PubMed: 10950233]

109. Mortimer KJ, Harrison TW, Tang Y, Wu K, Lewis S, Sahasranaman S, et al. Plasma concentrations of inhaled corticosteroids in relation to airflow obstruction in asthma. Br J Clin Pharmacol. 2006 Oct; 62(4):412-9. Epub 2006/09/26. eng. [PubMed: 16995862]

110. Adams NP, Bestall JC, Jones P, Lasserson TJ, Griffiths B, Cates CJ. Fluticasone at different doses for chronic asthma in adults and children. Cochrane Database Syst Rev. 2008; (4):CD003534. Epub 2008/10/10. eng. [PubMed: 18843646]

111. Cohen J, Douma WR, ten Hacken NH, Vonk JM, Oudkerk M, Postma DS. Ciclesonide improves measures of small airway involvement in asthma. Eur Respir J. 2008 Jun; 31(6):1213-20. Epub 2008/02/22. eng. [PubMed: 18287130]

112. Cohen J, Postma DS, Douma WR, Vonk JM, De Boer AH, ten Hacken NH. Particle size matters: diagnostics and treatment of small airways involvement in asthma. Eur Respir J. 2011 Mar; 37(3):532-40. Epub 2010/07/03. eng. [PubMed: 20595155]

113. Muller V, Galffy G, Eszes N, Losonczy G, Bizzi A, Nicolini G, et al. Asthma control in patients receiving inhaled corticosteroid and long-acting beta2-agonist fixed combinations. A real-life study comparing dry powder inhalers and a pressurized metered dose inhaler extrafine formulation. BMC Pulm Med. 2011; 11:40. Epub 2011/07/19. eng. [PubMed: 21762500]

114. Price D, Small I, Haughney J, Ryan D, Gruffydd-Jones K, Lavorini F, et al. Clinical and cost effectiveness of switching asthma patients from fluticasone-salmeterol to extra-fine particle beclometasone-formoterol: a retrospective matched observational study of real-world patients. Prim Care Respir J. 2013 Dec; 22(4):439-48. [PubMed: 24186700]

115. Colice G, Martin RJ, Israel E, Roche N, Barnes N, Burden A, et al. Asthma outcomes and costs of therapy with extrafine beclomethasone and fluticasone. J Allergy Clin Immunol. 2013 Jul; 132(1):45-54. [PubMed: 23591272]

116. Price D, Thomas M, Haughney J, Lewis RA, Burden A, von Ziegenweidt J, et al. Real-life comparison of beclometasone dipropionate as an extrafine- or larger-particle formulation for asthma. Respir Med. 2013 Jul; 107(7):987-1000. [PubMed: 23643486] 
117. Lasserson TJ, Cates CK, Jones AB, Steele EH, White J. Fluticasone versus HFA-beclomethasone dipropionate for chronic asthma in adults and children. Cochrane Database Syst Rev. 2006; (2):CD005309. [PubMed: 16625634]

118. Kramer S, Rottier BL, Scholten RJ, Boluyt N. Ciclesonide versus other inhaled corticosteroids for chronic asthma in children. Cochrane Database Syst Rev. 2013; 2:CD010352. [PubMed: 23450613]

119. Manning P, Gibson PG, Lasserson TJ. Ciclesonide versus placebo for chronic asthma in adults and children. Cochrane Database Syst Rev. 2008; (2):CD006217. [PubMed: 18425941]

120. Robroeks CM, van de Kant KD, van Vliet D, Kester AD, Hendriks HJ, Damoiseaux JG, et al. Comparison of the anti-inflammatory effects of extra-fine hydrofluoroalkane-beclomethasone vs fluticasone dry powder inhaler on exhaled inflammatory markers in childhood asthma. Ann Allergy Asthma Immunol. 2008 Jun; 100(6):601-7. [PubMed: 18592826]

121. van Staa TP, Cooper C, Leufkens HG, Bishop N. Children and the risk of fractures caused by oral corticosteroids. J Bone Miner Res. 2003 May; 18(5):913-8. Epub 2003/05/08. eng. [PubMed: 12733732]

122. Allen DB. Effects of inhaled steroids on growth, bone metabolism, and adrenal function. Adv Pediatr. 2006; 53:101-10. Epub 2006/11/09. eng. [PubMed: 17089864]

123. Pedersen S. Do inhaled corticosteroids inhibit growth in children? Am J Respir Crit Care Med. 2001 Aug 15; 164(4):521-35. Epub 2001/08/25. eng. [PubMed: 11520710]

124. Wechsler ME, Castro M, Lehman E, Chinchilli VM, Sutherland ER, Denlinger L, et al. Impact of Race on Asthma Treatment Failures in the Asthma Clinical Research Network. Am J Respir Crit Care Med. 2011 Sep 1. Epub ahead of print.

125. von Mutius E, Drazen JM. Choosing asthma step-up care. N Engl J Med. 2010 Mar 18; 362(11): 1042-3. Epub 2010/03/04. eng. [PubMed: 20197426]

126. Ducharme FM, Ni Chroinin M, Greenstone I, Lasserson TJ. Addition of long-acting beta2agonists to inhaled corticosteroids versus same dose inhaled corticosteroids for chronic asthma in adults and children. Cochrane Database Syst Rev. 2010 May 12.(5):CD005535. [PubMed: 20464739]

127. Lemanske RF Jr, Mauger DT, Sorkness CA, Jackson DJ, Boehmer SJ, Martinez FD, et al. Step-up therapy for children with uncontrolled asthma receiving inhaled corticosteroids. N Engl J Med. 2010 Mar 18; 362(11):975-85. Epub 2010/03/04. eng. [PubMed: 20197425]

128. Robinson DS, Campbell D, Barnes PJ. Addition of leukotriene antagonists to therapy in chronic persistent asthma: a randomised double-blind placebo-controlled trial. Lancet. 2001; 357(9273): 2007-11. [PubMed: 11438132]

129. Virchow JC Jr, Prasse A, Naya I, Summerton L, Harris A. Zafirlukast improves asthma control in patients receiving high-dose inhaled corticosteroids. Am J Respir Crit Care Med. 2000 Aug; 162(2 Pt 1):578-85. Epub 2000/08/10. eng. [PubMed: 10934090]

130. Lim S, Jatakanon A, Gordon D, Macdonald C, Chung KF, Barnes PJ. Comparison of high dose inhaled steroids, low dose inhaled steroids plus low dose theophylline, and low dose inhaled steroids alone in chronic asthma in general practice. Thorax. 2000 Oct; 55(10):837-41. Epub 2000/09/19. eng. [PubMed: 10992535]

131. Global Initiative For Asthma. 2014 GINA report, global strategy for asthma management and prevention 2014. Jun 25. 2014 Available from: http://www.ginasthma.org/2014-GINA-Report $\% 2 \mathrm{C}$-Global-Strategy-for-Asthma-Management-and-Prevention

132. Cox L, Nelson H, Lockey R, Calabria C, Chacko T, Finegold I, et al. Allergen immunotherapy: a practice parameter third update. J Allergy Clin Immunol. 2011 Jan; 127(1 Suppl):S1-55. [PubMed: 21122901]

133. Kim JM, Lin SY, Suarez-Cuervo C, Chelladurai Y, Ramanathan M, Segal JB, et al. Allergenspecific immunotherapy for pediatric asthma and rhinoconjunctivitis: a systematic review. Pediatrics. 2013 Jun; 131(6):1155-67. [PubMed: 23650298]

134. Kattan M, Mitchell H, Eggleston P, Gergen P, Crain E, Redline S, et al. Characteristics of innercity children with asthma: the National Cooperative Inner-City Asthma Study. Pediatr Pulmonol. 1997 Oct; 24(4):253-62. [PubMed: 9368259] 
135. Peters SP, Kunselman SJ, Icitovic N, Moore WC, Pascual R, Ameredes BT, et al. Tiotropium bromide step-up therapy for adults with uncontrolled asthma. N Engl J Med. 2010 Oct 28; 363(18):1715-26. [PubMed: 20979471]

136. Bateman ED, Kornmann O, Schmidt P, Pivovarova A, Engel M, Fabbri LM. Tiotropium is noninferior to salmeterol in maintaining improved lung function in B16-Arg/Arg patients with asthma. J Allergy Clin Immunol. 2011 Aug; 128(2):315-22. Epub 2011/08/03. eng. [PubMed: 21807250]

137. Kerstjens HA, Disse B, Schroder-Babo W, Bantje TA, Gahlemann M, Sigmund R, et al. Tiotropium improves lung function in patients with severe uncontrolled asthma: A randomized controlled trial. J Allergy Clin Immunol. 2011 Aug; 128(2):308-14. Epub 2011/06/04. eng. [PubMed: 21636120]

138. Kerstjens HA, Engel M, Dahl R, Paggiaro P, Beck E, Vandewalker M, et al. Tiotropium in asthma poorly controlled with standard combination therapy. N Engl J Med. 2012 Sep 27; 367(13):1198-207. [PubMed: 22938706]

139. Peters SP, Bleecker ER, Kunselman SJ, Icitovic N, Moore WC, Pascual R, et al. Predictors of response to tiotropium versus salmeterol in asthmatic adults. J Allergy Clin Immunol. 2013 Nov; 132(5):1068-74. e1. [PubMed: 24084072]

140. Milgrom H, Berger W, Nayak A, Gupta N, Pollard S, McAlary M, et al. Treatment of childhood asthma with anti-immunoglobulin E antibody (omalizumab). Pediatrics. 2001; 108(2):E36. [PubMed: 11483846]

141. Lemanske RF Jr, Nayak A, McAlary M, Everhard F, Fowler-Taylor A, Gupta N. Omalizumab improves asthma-related quality of life in children with allergic asthma. Pediatrics. 2002; 110(5):e55. [PubMed: 12415061]

142. Humbert M, Beasley R, Ayres J, Slavin R, Hebert J, Bousquet J, et al. Benefits of omalizumab as add-on therapy in patients with severe persistent asthma who are inadequately controlled despite best available therapy (GINA 2002 step 4 treatment): INNOVATE. Allergy. 2005; 60(3):309-16. [PubMed: 15679715]

143. Busse WW, Morgan WJ, Gergen PJ, Mitchell HE, Gern JE, Liu AH, et al. Randomized trial of omalizumab (anti-IgE) for asthma in inner-city children. N Engl J Med. 2011 Mar 17; 364(11): 1005-15. Epub 2011/03/18. eng. [PubMed: 21410369]

144. Wenzel SE, Robinson CB, Leonard JM, Panettieri RA Jr. Nebulized dehydroepiandrosterone-3sulfate improves asthma control in the moderate-to-severe asthma results of a 6-week, randomized, double-blind, placebo-controlled study. Allergy Asthma Proc. 2010 Nov-Dec;31(6): 461-71. [PubMed: 21708057]

145. Wenzel SE, Wang L, Pirozzi G. Dupilumab in persistent asthma. N Engl J Med. 2013 Sep 26.369(13):1276. [PubMed: 24066755]

146. Corren J, Lemanske RF, Hanania NA, Korenblat PE, Parsey MV, Arron JR, et al. Lebrikizumab treatment in adults with asthma. N Engl J Med. 2011 Sep 22; 365(12):1088-98. Epub 2011/08/05. eng. [PubMed: 21812663]

147. Pavord ID, Korn S, Howarth P, Bleecker ER, Buhl R, Keene ON, et al. Mepolizumab for severe eosinophilic asthma (DREAM): a multicentre, double-blind, placebo-controlled trial. Lancet. 2012 Aug 18; 380(9842):651-9. [PubMed: 22901886]

148. Castro M, Mathur S, Hargreave F, Boulet LP, Xie F, Young J, et al. Reslizumab for Poorly Controlled, Eosinophilic Asthma: A Randomized, Placebo-Controlled Study. Am J Respir Crit Care Med. 2011 Aug 18. Epub 2011/08/20. Eng.

149. Nair P, Pizzichini MM, Kjarsgaard M, Inman MD, Efthimiadis A, Pizzichini E, et al. Mepolizumab for prednisone-dependent asthma with sputum eosinophilia. N Engl J Med. 2009; 360(10):985-93. [PubMed: 19264687]

150. Coren ME, Rosenthal M, Bush A. The use of cyclosporin in corticosteroid dependent asthma. Arch Dis Child. 1997 Dec; 77(6):522-3. Epub 1998/03/13. eng. [PubMed: 9496189]

151. Cox G, Thomson NC, Rubin AS, Niven RM, Corris PA, Siersted HC, et al. Asthma control during the year after bronchial thermoplasty. N Engl J Med. 2007 Mar 29; 356(13):1327-37. [PubMed: 17392302] 
152. Pavord ID, Cox G, Thomson NC, Rubin AS, Corris PA, Niven RM, et al. Safety and efficacy of bronchial thermoplasty in symptomatic, severe asthma. Am J Respir Crit Care Med. 2007 Dec 15; 176(12):1185-91. [PubMed: 17901415]

153. Castro M, Rubin A, Laviolette M, Hanania NA, Armstrong B, Cox G, et al. Persistence of effectiveness of bronchial thermoplasty in patients with severe asthma. Ann Allergy Asthma Immunol. 2011 Jul; 107(1):65-70. [PubMed: 21704887]

154. Castro M, Rubin AS, Laviolette M, Fiterman J, De Andrade Lima M, Shah PL, et al. Effectiveness and safety of bronchial thermoplasty in the treatment of severe asthma: a multicenter, randomized, double-blind, sham-controlled clinical trial. Am J Respir Crit Care Med. 2010 Jan 15; 181(2):116-24. [PubMed: 19815809]

155. Torrego A, Sola I, Munoz AM, Roque IFM, Yepes-Nunez JJ, Alonso-Coello P, et al. Bronchial thermoplasty for moderate or severe persistent asthma in adults. Cochrane Database Syst Rev. 2014; 3:CD009910. [PubMed: 24585221]

156. Pavord ID, Thomson NC, Niven RM, Corris PA, Chung KF, Cox G, et al. Safety of bronchial thermoplasty in patients with severe refractory asthma. Ann Allergy Asthma Immunol. 2013 Nov; 111(5):402-7. [PubMed: 24125149]

157. Wechsler ME, Laviolette M, Rubin AS, Fiterman J, Lapa e Silva JR, Shah PL, et al. Bronchial thermoplasty: Long-term safety and effectiveness in patients with severe persistent asthma. J Allergy Clin Immunol. 2013 Dec; 132(6):1295-302. [PubMed: 23998657]

158. Thomson NC, Rubin AS, Niven RM, Corris PA, Siersted HC, Olivenstein R, et al. Long-term (5 year) safety of bronchial thermoplasty: Asthma Intervention Research (AIR) trial. BMC Pulm Med. 2011; 11:8. [PubMed: 21314924]

159. ten Brinke A, van Dissel JT, Sterk PJ, Zwinderman AH, Rabe KF, Bel EH. Persistent airflow limitation in adult-onset nonatopic asthma is associated with serologic evidence of Chlamydia pneumoniae infection. J Allergy Clin Immunol. 2001 Mar; 107(3):449-54. Epub 2001/03/10. eng. [PubMed: 11240944]

160. Kostadima E, Tsiodras S, Alexopoulos EI, Kaditis AG, Mavrou I, Georgatou N, et al. Clarithromycin reduces the severity of bronchial hyperresponsiveness in patients with asthma. Eur Respir J. 2004 May; 23(5):714-7. Epub 2004/06/05. eng. [PubMed: 15176685]

161. Strunk RC, Bacharier LB, Phillips BR, Szefler SJ, Zeiger RS, Chinchilli VM, et al. Azithromycin or montelukast as inhaled corticosteroid-sparing agents in moderate-to-severe childhood asthma study. J Allergy Clin Immunol. 2008 Dec; 122(6):1138-44. e4. Epub 2008/10/28. eng. [PubMed: 18951618]

162. Bush A. Phenotype specific treatment of asthma in childhood. Paediatr Respir Rev. 2004; 5(Suppl A):S93-101. Epub 2004/02/26. eng. [PubMed: 14980251]

163. Vicencio AG, Muzumdar H, Tsirilakis K, Kessel A, Nandalike K, Goldman DL. Severe asthma with fungal sensitization in a child: response to itraconazole therapy. Pediatrics. 2010 May; 125(5):e1255-8. [PubMed: 20385639]

164. Cote J, Bowie DM, Robichaud P, Parent JG, Battisti L, Boulet LP. Evaluation of two different educational interventions for adult patients consulting with an acute asthma exacerbation. Am J Respir Crit Care Med. 2001 May; 163(6):1415-9. Epub 2001/05/24. eng. [PubMed: 11371411]

165. Wenzel S, Szefler SJ. Managing severe asthma. J Allergy Clin Immunol. 2006 Mar; 117(3):50811. Epub 2006/03/09. eng. [PubMed: 16522447]

166. Chanez P, Wenzel SE, Anderson GP, Anto JM, Bel EH, Boulet LP, et al. Severe asthma in adults: what are the important questions? J Allergy Clin Immunol. 2007 Jun; 119(6):1337-48. Epub 2007/04/10. eng. [PubMed: 17416409]

167. Okelo SO, Wu AW, Krishnan JA, Rand CS, Skinner EA, Diette GB. Emotional quality-of-life and outcomes in adolescents with asthma. J Pediatr. 2004 Oct; 145(4):523-9. [PubMed: 15480379]

168. Okelo SO, Eakin MN, Riekert KA, Teodoro AP, Bilderback AL, Thompson DA, et al. Validation of parental reports of asthma trajectory, burden, and risk by using the pediatric asthma control and communication instrument. The journal of allergy and clinical immunology In practice. 2014 Mar-Apr;2(2):186-92. e7. [PubMed: 24607047] 
169. Annett RD, Bender BG, Skipper B, Allen C. Predicting moderate improvement and decline in pediatric asthma quality of life over 24 months. Qual Life Res. 2010 Dec; 19(10):1517-27. [PubMed: 20680689]

170. Bel EH, Sousa A, Fleming L, Bush A, Chung KF, Versnel J, et al. Diagnosis and definition of severe refractory asthma: an international consensus statement from the Innovative Medicine Initiative (IMI). Thorax. 2011 Oct; 66(10):910-7. [PubMed: 21106547] 


\section{Table 1}

\section{Definitions of Severe Asthma}

\begin{tabular}{|c|c|}
\hline $\begin{array}{l}\text { NAEPP guideline definition } \\
\text { before treatment }(97)\end{array}$ & $\begin{array}{l}\text { Criteria for Severe Persistent Asthma in Children } 0-4 \text { and } 5-11 \text { years: } \\
\text { - } \quad \text { Symptoms: throughout the day } \\
\text { - } \quad \text { Usight-time awakenings: }>1 \mathrm{x} / \text { week } \\
\text { - } \quad \text { Interference with normal activity: } \\
\text { Extremely limited } \\
\text { Lung Function: }(0-4 \text { years }) \mathrm{N} / \mathrm{A} ;(5-11 \text { years }) \text { FEV1 or peak flow (personal best })<60 \% \\
\text { predicted or FEV1/FVC }<75 \% \text { predicted; } \\
\text { Risk: (0-4 years) }>2 \text { exacerbations in } 6 \text { months requiring oral systemic corticosteroids or }>4 \\
\text { wheezing episodes/1 year lasting }>1 \text { day AND risk factors for persistent asthma; }(5-11 \text { years) } \\
>2 \text { exacerbations in } 12 \text { months requiring oral systemic corticosteroids OR relative annual } \\
\text { risk may be related to FEV1 }\end{array}$ \\
\hline $\begin{array}{l}\text { GINA guideline definition before } \\
\text { treatment }(41)\end{array}$ & 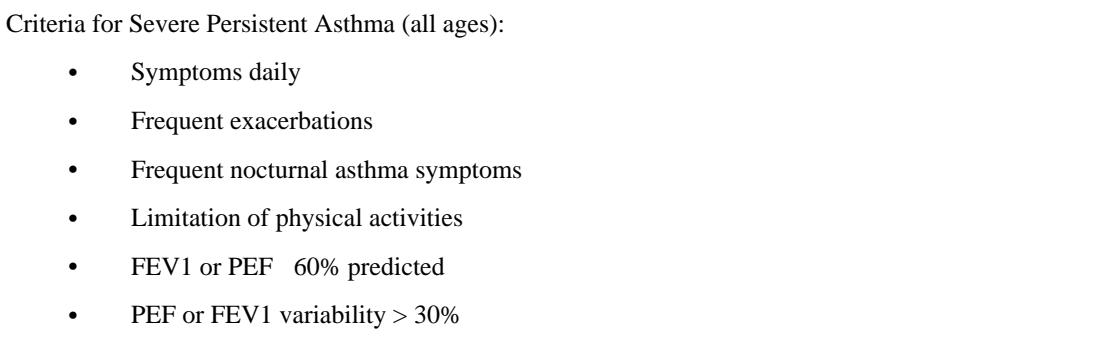 \\
\hline ATS/ERS definition (2014)(27) & $\begin{array}{l}\text { Criteria for Severe Asthma: } \\
\text { Asthma which requires treatment with high-dose ICS plus at least one additional controller } \\
\text { medication for the previous year (or systemic corticosteroids for }>50 \% \text { of the previous year). } \\
\text { AND EITHER } \\
\text { - Uncontrolled asthma (must have one) } \\
\text { _ } \quad \text { Poor asthma control (ACQ }>1.5, \text { ACT }<20) \\
\text { - } \quad \text { Two or more systemic CS bursts in the previous year } \\
\text { - } \quad \text { Airflow limitation with FEV1<80\% after bronchodilator } \\
\text { OR } \quad \text { Controlled asthma that worsens with tapering of high doses of ICS or systemic CS }\end{array}$ \\
\hline
\end{tabular}


Table 2

Co-morbidities and Additional Diagnoses that may exacerbate asthma severity of mimic asthma (modified from Bel EH et al(170)).

\begin{tabular}{|c|c|}
\hline Suspected comorbidity or additional diagnoses & Diagnostic Test or Evaluation \\
\hline $\begin{array}{l}\text { Structural Abnornality (airway malacia, vascular rings/slings, tracheal } \\
\text { stenosis/webs, cystic lesions/masses, tumors/lymphadenopathy/ } \\
\text { cardiomegaly) }\end{array}$ & $\begin{array}{l}\text { Fiberoptic bronchoscopy } \\
\text { Lung CT scan }\end{array}$ \\
\hline Intrabronchial obstruction (e.g. inhaled foreign body, tuberculosis) & Fiberoptic or rigid bronchoscopy \\
\hline Dysfunction breathing (e.g. vocal cord dysfunction, panic attacks) & $\begin{array}{l}\text { Fiberoptic bronchoscopy } \\
\text { Speech therapy evaluation }\end{array}$ \\
\hline $\begin{array}{l}\text { Aspiration (e.g. neuromuscular disease, developmental abnormality, } \\
\text { swallowing disorder) }\end{array}$ & Swallow evaluation \\
\hline Gastroesophageal reflux with/without recurrent microaspiration & $\begin{array}{l}\mathrm{pH} \text { or impedence probe study } \\
\text { Eophagogastroduodenoscopy }(E G D)\end{array}$ \\
\hline Cystic Fibrosis & $\begin{array}{l}\text { Sweat Chloride Test } \\
\text { Genetic screening }\end{array}$ \\
\hline Ciliary Dyskinesia & Ciliary biopsy \\
\hline Immune Dysfunction & $\begin{array}{l}\text { Serum immunoglobulins including } \mathrm{IgA}, \mathrm{G}, \mathrm{M} \text { and } \mathrm{IgG} \\
\text { subclasses and vaccine antibody responses (Haemophilus, } \\
\text { tetanus and Pneumococcus) }\end{array}$ \\
\hline $\begin{array}{l}\text { Bronchiectasis (e.g. cystic fibrosis, primary ciliary dyskinesia, immune } \\
\text { dysfunction) }\end{array}$ & High resolution Lung CT scan \\
\hline Pulmonary Edema (e.g. cardiac disorder) & $\begin{array}{l}\text { Chest radiography } \\
\text { Echocardiogram }\end{array}$ \\
\hline Lung disease of prematurity & History of prematurity \\
\hline Bronchiolitis obliterans syndrome & $\begin{array}{l}\text { High resolution Lung CT scan } \\
\text { Lung biopsy }\end{array}$ \\
\hline Sinusitis & Sinus CT scan \\
\hline $\begin{array}{l}\text { Hypersensitivity pneumonitis (e.g. allergic bronchopulmonary } \\
\text { aspergillosis, bird aeroallergen sensitivity) }\end{array}$ & $\begin{array}{l}\text { Aspergillus IgE/precipitins/sputum culture } \\
\text { Bird IgE/antigen precipitins/exposure history }\end{array}$ \\
\hline Psychological Factors (Depression/Anxiety) & Psychological Screening/Evaluation \\
\hline Obesity & BMI \\
\hline
\end{tabular}

